\title{
Comparison Study of a Natural Non-Antibiotic Growth Promoter and a Commercial Probiotic on Growth Performance, Immune Response and Biochemical Parameters of Broiler Chicks
}

\author{
Milad Manafi \\ Department of Animal Science, Faculty of Agricultural Sciences, Malayer University, Malayer, Iran
}

\begin{abstract}
The objective of the present study was to investigate the effectiveness of a non-antibiotic growth promoter (NonAGP) which is a combination of phytomolecules, direct-fed microbials (DFMs) and organic acids on performance, serum enzyme activities, immune response and visceral organ weights of commercial broiler chickens. A total of 375 day-old Ross 308 broiler chickens (mixed sex) were obtained from a local hatchery, weighed, and randomly allotted to 5 treatment groups with 5 replicates of 15 birds each. They received different treatments as basal diet (control); control plus $400 \mathrm{mg} / \mathrm{kg}$ bacitracin methylene disalicylate (BMD); control plus $0.05 \%$ Non-AGP (Non-AGP1); control plus $0.1 \%$ Non-AGP (Non-AGP2) and control plus $0.1 \%$ commercial probiotic (PRO). Chicks fed BMD resulted in maximum feed efficiency and a significant $(P \leq 0.05)$ increase in the body weight, relative weights of liver, kidney and pancreas and Newcastle disease (ND), Infectious Bursal Disease (IBD) and Avian Influenza (AI) titers at d 42. Dietary inclusion of Non-AGP at the level of $0.1 \%$ into the basal diet proved its efficiency equal to BMD fed chicks, whereas addition of a probiotic at the level of $0.1 \%$ showed its applicability similar to the control group. It is concluded that the tested Non-AGP product at $0.1 \%$ but not $0.05 \%$ in the current study may be a suitable replacement for BMD in poultry diets.
\end{abstract}

Key words: broiler chicks, immune response, performance, phytogenic feed additive

J. Poult. Sci., 52: 274-281, 2015

\section{Introduction}

Application of antibiotic growth promoters (AGPs) has been a very common method for growth promotion, prevention of common diseases, and enhancement of immune response in commercial poultry production (Yeo et al., 1997). It is generally known that the use of feed antibiotics at sub-therapeutic levels is responsible for development of drug resistance in bacteria (Patterson et al., 2003). Resistant bacteria could become more harmful over a period of prolonged exposure to lower doses of antibiotics (Patterson et al., 2003). Drug resistant bacteria are responsible for some antibiotic failure in human beings as the final consumer of poultry products (Windisch et al., 2008). Consequently, many countries have banned the usage of AGP and the concern is spreading to other countries as well. The removal of AGP from poultry diets has initiated a search for suitable natural alternatives to combat the increased potential for

Received: February 6, 2015, Accepted: April 21, 2015

Released Online Advance Publication: June 25, 2015

Correspondence: Dr. M. Manafi, Department of Animal Science, Faculty

of Agricultural Sciences, Malayer University, Malayer, Iran.

(E-mail: manafim@malayeru.ac.ir) bacterial disease development in growing flocks especially under poor management conditions. Several potential alternative feed additives to AGP include phytogenic compounds, direct-fed microbials (DFM), different herbs or spices, essential oils, acidifiers, organic acids, prebiotics and probiotics and selected phytomolecules (Young et al., 2003; Stanaćev et al., 2008). Currently, a number of publications (Hammer et al., 2001; Young et al., 2003; Stanaćev et al., 2008; Windisch et al., 2008) considered augmented application of several plant materials which contain valuable phytogenic ingredients as dietary supplements in poultry diets. Many of these herbal combinations have shown a positive impact on poultry health and productivity (Hammer et al., 2001). Phytomolecules, however, are a relatively new class of feed additives, and our knowledge is still rather limited regarding their modes of action and aspects of their true application. Further complications arise because phytogenic feed additives may vary widely with respect to botanical origin, processing, and composition (Kamel, 2001). Within the group of phytogenic feed additives, a large variety of substances and an even larger number of active ingredients can vary substantially in chemical composition. In some studies, phytogenic supplements have been reported to have 
positive effects on broiler performance (Reisinger et al., 2011). Given the nearly global ban of AGPs, we carried out an in vivo experiment to assess the efficiency and the safety of a plant derived compound $\left(\mathrm{Natusol}^{\mathbb{R}}\right.$ ) for poultry. Therefore, the purpose of this study was to investigate the two levels of a commercial phytogenic compound and compare it with an AGP and commercial probiotic on performance, biochemical activities, immune response and visceral organ weights of chicks.

\section{Materials and Methods}

\section{Experimental Protocol and Sample Correction}

Three hundred and seventy five 1-day old healthy Ross $\mathrm{x}$ Ross 308 chicks (mixed sex) were obtained from a local hatchery, and were weighed and randomly allocated to 5 treatment groups with 5 replicates of 15 birds each. The chickens were fed a coccidiostat-free corn-soybean meal basal diet (control); control plus $400 \mathrm{mg} / \mathrm{kg}$ bacitracin methylene disalicylate (BMD); control plus 0.05\% Non-AGP (Non-AGP1); control plus 0.1\% Non-AGP (Non-AGP2) and control plus $0.1 \%$ commercial probiotic for 42 days. The Non-AGP used in this study was Natusol ${ }^{\circledR}$ (a combination of phytomolecules, DFMs, glucamannan oligosaccharides and organic acids) provided by a commercial company (Zeus Biotech Limited, Mysore, India). The commercial probiotic used in this study was Calsporin ${ }^{\circledR}$, a combination of spraydried spore-forming B. subtilisC-3102 provided by Calpis Co. Ltd., Japan. Each diet was randomly assigned to one of 5 groups of chicks. The feeding regimen consisted of a starter ( 1 to $10 \mathrm{~d}$ ), grower ( 11 to $24 \mathrm{~d}$ ), and finisher diet ( 25 to $42 \mathrm{~d}$ ). The diets were provided as mash and prepared with the same batch of ingredients for starter, grower, and finisher periods and were formulated to meet the nutrient requirements according to Ross-308 Aviagen rearing guidelines (Aviagen, 2007). All birds had free access to feed and water. The ingredients and calculated chemical composition of the basal diets are shown in Table 1.

The Non-AGP, probiotic and bacitracin methylene disalicylate were procured from the local market, supplied in powder form and were included to the basal diet according to experimental treatments by creating a premix to ensure proper disbursement of the materials throughout the basal diet. Replicate groups of chicks were housed in independent pens $(1.5 \times 2.5 \mathrm{~m})$, in a conventional sided deep litter house

Table 1. Ingredients and composition of the basal diets (as-fed basis)

\begin{tabular}{|c|c|c|c|}
\hline $\begin{array}{l}\text { Item } \\
\text { Ingredient (\%) }\end{array}$ & $\begin{array}{l}\text { Starter } \\
(1-10 \mathrm{~d})\end{array}$ & $\begin{array}{l}\text { Grower } \\
(11-24 d)\end{array}$ & $\begin{array}{l}\text { Finisher } \\
(25-42 d)\end{array}$ \\
\hline Corn $(8 \% \mathrm{CP})$ & 53.20 & 55.88 & 57.25 \\
\hline Soybean meal (43\% CP) & 38.41 & 34.90 & 33.31 \\
\hline Wheat bran & 2.02 & 2.02 & 2.02 \\
\hline Vegetable oil & 2.08 & 3.60 & 4.10 \\
\hline Limestone & 1.30 & 1.10 & 1.04 \\
\hline Dicalcium phosphate & 1.65 & 1.40 & 1.31 \\
\hline Salt & 0.42 & 0.42 & 0.40 \\
\hline DL-Met & 0.15 & 0.10 & 0.07 \\
\hline HCI-Lys & 0.21 & 0.08 & 0.00 \\
\hline Thr & 0.06 & 0.00 & 0.00 \\
\hline Vitamin premix $^{\mathrm{a}}$ & 0.25 & 0.25 & 0.25 \\
\hline Mineral premix ${ }^{b}$ & 0.25 & 0.25 & 0.25 \\
\hline \multicolumn{4}{|c|}{ Calculated chemical composition (\%, unless otherwise noted) } \\
\hline Metabolizable energy (kcal/kg) & 2850 & 2970 & 3020 \\
\hline Crude protein & 22.1 & 20.7 & 19.8 \\
\hline $\mathrm{Ca}$ & 1.00 & 0.85 & 0.80 \\
\hline Available phosphorous & 0.47 & 0.42 & 0.39 \\
\hline Sodium & 0.18 & 0.18 & 0.17 \\
\hline Lys & 1.35 & 1.17 & 1.03 \\
\hline Met & 0.48 & 0.42 & 0.39 \\
\hline Met + Cys & 1.01 & 0.90 & 0.81 \\
\hline Thr & 0.89 & 0.78 & 0.70 \\
\hline
\end{tabular}

Di-calcium phosphate contained: $16 \%$ phosphorous and $23 \%$ calcium.

${ }^{a}$ Vitamin premix provided the following per kilogram of diet: vitamin A (trans-retinyl acetate), 10,000 IU; vitamin $\mathrm{D}_{3}$ (cholecalciferol), 3,500 IU; vitamin $\mathrm{E}$ (DL- $\alpha$-tocopheryl acetate), $60 \mathrm{mg}$; vitamin $\mathrm{K}$ (menadione), $3 \mathrm{mg}$; thiamine, $3 \mathrm{mg}$; riboflavin, $6 \mathrm{mg}$; pyridoxine, $5 \mathrm{mg}$; vitamin $\mathrm{B}_{12}$ (cyanocobalamin), $0.01 \mathrm{mg}$; niacin, $45 \mathrm{mg}$; pantothenic acid (D-calcium pantothenate), $11 \mathrm{mg}$; folic acid, $1 \mathrm{mg}$; biotin, $0.15 \mathrm{mg}$; choline chloride, $500 \mathrm{mg}$; ethoxyquin (antioxidant), $150 \mathrm{mg}$.

${ }^{\mathrm{b}}$ Mineral premix provided the following per kilogram of diet: Fe, $60 \mathrm{mg}$; Mn, $100 \mathrm{mg}$; Zn, 60 $\mathrm{mg}$; Cu, $10 \mathrm{mg}$; I, $1 \mathrm{mg}$; Co, $0.2 \mathrm{mg}$; Se, $0.15 \mathrm{mg}$. 
at the Malayer University Experimental Poultry Farm in Iran. All chicks were exposed to $23 \mathrm{~h}$ light with 30 lux light intensity for the first $7 \mathrm{~d}$, followed by 10 lux light intensity for the rest of the study. Temperature was initially set at $32^{\circ} \mathrm{C}$ on $\mathrm{d} 1$ and decreased linearly by $0.5^{\circ} \mathrm{C}$ per day to a temperature of $21^{\circ} \mathrm{C}$ by the thermostatically controlled whole house heating system.

\section{Vaccination Schedule}

The local office of the Iranian Veterinary Organization suggested the required local vaccination and managed by the veterinarian of Malayer University, as below:

Essential Newcastle Disease (ND) vaccination was carried out on the first day (by spray in the hatchery), and repeated on the $12^{\text {th }}$ day as CEVAC $^{\circledR}$ BI L contains the Hitchner B1 strain of Newcastle Disease virus in live, freeze dried form) in the drinking water, with a booster on the 20th day as clone30 (HIPRAVIAR ${ }^{\circledR}$ ) in the drinking water. Vaccination against Infectious Bronchitis ensued twice as the following: first spray at commencement of the experiment and the booster in the drinking water on the $10^{\text {th }}$ day, both as H-120 $\left(\right.$ CEVAC $\left.^{\mathbb{B}}\right)$. Vaccination against Infection Bursal Disease (IBD) was carried out twice: first on day 15 and the second on the $24^{\text {th }}$ day, both as Gambo-1 $\left(\right.$ CEVAC $\left.^{\circledR}\right)$ in the drinking water. The booster B1 neurotropic vaccine strain virus (ND $6 / 10)\left(\right.$ CEVAC $\left.^{\circledR}\right)$ was provided in the drinking water at the age of $21 \mathrm{~d}$, after measuring the hemagglutination inhibition (HI) titer test of sera to determine levels of $\mathrm{Ab}$ to ND in the blood.

\section{Studied Parameters \\ Performance}

All birds were weighed individually after arrival at the farm and on 7, 14, 21, 28,35 and $42 \mathrm{~d}$ using a digital electronic top pan balance with $0.1 \mathrm{~g}$ accuracy to record live body weight. Feed consumption was recorded on a pen basis by measuring left over feed at the same time as the live weight recording. Feed conversion ratio (FCR) was calculated as the feed to gain ratio.

\section{Biochemical Parameters and Immune Response}

On d 21 and d 42, two birds per replicate, for a total of 10 birds (mixed sex) per treatment, were selected randomly for blood sampling via the jugular vein. Blood was collected individually in $10-\mathrm{ml}$ non-anticoagulant heparinized tubes. Blood samples were centrifuged at $900 \times g$ for $10 \mathrm{~min}$ at $4^{\circ} \mathrm{C}$ to obtain sera, which were then stored at $-20^{\circ} \mathrm{C}$ for the determination of serum biochemical and immune parameters. The individual serum samples were analyzed for antibody titers against Newcastle Disease (ND), Infectious Bursal Disease (IBD) and Avian Influenza (AI) by ELISA technique (at d 21 and d 42). Albumin, globulin, total protein, alanine amino transferase (ALT), gamma glutamyl transferase (GGT) and alkaline phosphatase (ALP) were evaluated at d 42 using a Hitachi 704 automatic clinical chemistry analyzer (Boehringer Mannhein Hitachi 704). The methodology and the set of reagents used in respect to each parameter were as recommended by the manufacturer of the analyzer system. Treatment-wise mean of values were computed and presented as means \pm SEM of each treatment.

\section{Measurement of Visceral Organs}

At the end of the trial, upon obtaining the permission of the Ethical Committee of the University, ten birds from each treatment were randomly selected and killed by cutting the jugular vein. Each bird was weighed individually, then the abdominal cavity of each bird was opened and liver, kidney, pancreas, gizzard thymus, spleen and the Bursa of Fabricius were removed. The weight of thymus, spleen and the Bursa of Fabricius were weighed on a mono pan balance $(0.1 \mathrm{mg}$ accuracy) and the liver, kidney, pancreas and gizzard were weighed on a digital top pan balance ( $0.1 \mathrm{~g}$ accuracy). The weights were adjusted to one $\mathrm{kg}$ live weight and treatment means were calculated.

\section{Statistical Analysis}

Data were subjected to one-way ANOVA analysis using the GLM procedure of SAS 9.0 (SAS, 2001). The data were analyzed weekly or overall as needed using a completely randomized design to examine the overall effect of treatments. Pen means were used as the experimental units for all variables evaluated. The mean differences were compared using Duncan's multiple range tests (Duncan, 1955). Significance was declared when the probability was less than $5 \%(P \leq 0.05)$.

\section{Results}

\section{Performance}

All day-old chicks in the present study had a similar body weight and this trend remained un-changed up to $\mathrm{d} 28$. At day 35 , antibiotic growth promoter (BMD) and Non-AGP2 groups have shown a significant $(P \leq 0.05)$ increase in $\mathrm{BW}$ while the PRO and Non-AGP1 treatments showed no statistical difference compared with the control group. At the end of the trial (d 42), BW and FCR of BMD, Non-AGP1 and Non-AGP2 groups showed a significant $(P \leq 0.05)$ improvement compared to the control. These parameters remained non-significant in PRO fed group, whereas in BMD and Non-AGP2 treatments had a significantly lower FCR than the Non-AGP1 treatment (Table 2).

\section{Serum Enzyme Activities}

Chicks fed different dietary treatments have shown no statistical $(P \leq 0.05)$ changes for serum albumin, serum globulin, total protein, ALT and GGT at d 42, when compared with the control group (Table 3 ). Only ALP values have significantly $(P \leq 0.05)$ decreased in both the Non-AGP levels used in this study, compared with BMD treatment; whereas, in the PRO group, this value was not significantly $(P \leq 0.05)$ different from other treatments.

\section{Immune Response}

No significant $(P \leq 0.05)$ variation in the antibody titer values for ND, IBD and AI have been found at d 21, among all dietary treatments (Table 4). At 42 days of age, the antibody titers in BMD and Non-AGP2 groups were increased significantly $(P \leq 0.05)$ when compared with their respective control group or other treatments.

\section{Visceral Organ Weights}

As shown in Table 5, the relative weights of thymus, spleen and gizzard did not show any significant $(P \leq 0.05)$ 
Table 2. Dietary effect of BMD, Non-AGP and PRO on performance of chicks ${ }^{1}$

\begin{tabular}{|c|c|c|c|c|c|}
\hline & & & Treatments & & \\
\hline Item & Control & BMD & Non-AGP1 & Non-AGP2 & PRO \\
\hline \multicolumn{6}{|c|}{ Average body weight } \\
\hline $1 d$ & $43.66 \pm 1.20$ & $42.66 \pm 2.60$ & $43.66 \pm 1.45$ & $42.66 \pm 1.45$ & $42.66 \pm 2.07$ \\
\hline $1-7 d$ & $176.66 \pm 1.76$ & $177.00 \pm 2.00$ & $176.33 \pm 1.20$ & $175.66 \pm 0.66$ & $175.66 \pm 1.20$ \\
\hline $8-14 d$ & $450.00 \pm 3.51$ & $452.00 \pm 2.30$ & $456.00 \pm 3.60$ & $453.00 \pm 7.02$ & $451.00 \pm 5.50$ \\
\hline $15-21 d$ & $862.33 \pm 21.17$ & $889.00 \pm 7.57$ & $877.00 \pm 9.03$ & $887.66 \pm 8.41$ & $863.66 \pm 7.42$ \\
\hline $22-28 d$ & $1381.00 \pm 54.60$ & $1419.67 \pm 26.52$ & $1395.33 \pm 8.56$ & $1401.67 \pm 9.24$ & $1381.00 \pm 54.60$ \\
\hline $29-35 d$ & $1975.33 \pm 5.23^{\mathrm{b}}$ & $2043.67 \pm 34.06^{\mathrm{a}}$ & $2021.33 \pm 3.84^{\mathrm{ab}}$ & $2039.00 \pm 4.16^{\mathrm{a}}$ & $1975.00 \pm 9.45^{\mathrm{b}}$ \\
\hline $35-42 d$ & $2500.67 \pm 11.56^{\mathrm{b}}$ & $2684.00 \pm 42.22^{\mathrm{a}}$ & $2644.00 \pm 54.72^{\mathrm{a}}$ & $2676.33 \pm 43.34^{\mathrm{a}}$ & $2502.33 \pm 48.88^{\mathrm{b}}$ \\
\hline \multicolumn{6}{|c|}{ Feed consumption } \\
\hline $1-42 d$ & $4673.75 \pm 29.62$ & $4721.15 \pm 82.50$ & $4722.18 \pm 95.64$ & $4710.34 \pm 72.80$ & $4651.83 \pm 87.80$ \\
\hline \multicolumn{6}{|c|}{ Feed conversion ratio } \\
\hline $1-42 d$ & $1.869 \pm 0.003^{\mathrm{a}}$ & $1.759 \pm 0.003^{\mathrm{c}}$ & $1.786 \pm 0.004^{\mathrm{b}}$ & $1.760 \pm 0.001^{\mathrm{c}}$ & $1.859 \pm 0.004^{\mathrm{a}}$ \\
\hline
\end{tabular}

${ }^{\mathrm{a}-\mathrm{c}}$ Mean $\pm \mathrm{SE}$ values in a same row with different superscripts are significantly different $(P \leq 0.05)$.

${ }^{1}$ Day-old broiler chicks were fed a corn-soybean meal based control diet. Control: without BMD, Non-AGP and PRO supplementation; BMD: control plus $400 \mathrm{mg} / \mathrm{kg}$ bacitracin methylene disalicylate; Non-AGP1: control plus 0.05\% Non-AGP, Non-AGP2: control plus 0.1\% NonAGP; PRO: control plus $0.1 \%$ commercial probiotic for 42 days. Individual weekly average body weight ( $\mathrm{g}$ ) and feed consumption ( $\mathrm{g} / \mathrm{chick}$ ) per replicate were measured and used to calculate feed conversion ratio (FCR).

Table 3. Dietary effect of BMD, Non-AGP and PRO on serum enzyme activities of chicks at 42 days ${ }^{1}$

\begin{tabular}{|c|c|c|c|c|c|}
\hline & & & Treatments & & \\
\hline Item & Control & BMD & Non-AGP1 & Non-AGP2 & PRO \\
\hline Serum albumin $(\mathrm{g} \%)$ & $1.41 \pm 0.04$ & $1.39 \pm 0.02$ & $1.37 \pm 0.02$ & $1.40 \pm 0.02$ & $1.35 \pm 0.01$ \\
\hline Serum globulin $(\mathrm{g} \%)$ & $1.01 \pm 0.08$ & $1.08 \pm 0.09$ & $1.02 \pm 0.06$ & $1.07 \pm 0.10$ & $0.99 \pm 0.05$ \\
\hline Total protein $(\mathrm{g} \%)$ & $2.36 \pm 0.05$ & $2.48 \pm 0.06$ & $2.39 \pm 0.03$ & $2.47 \pm 0.08$ & $2.36 \pm 0.06$ \\
\hline $\operatorname{ALT}(\mathrm{IU} / \mathrm{L})^{2}$ & $28.58 \pm 0.09$ & $29.27 \pm 0.32$ & $28.68 \pm 0.23$ & $28.11 \pm 0.33$ & $28.53 \pm 0.42$ \\
\hline GGT $(\mathrm{IU} / \mathrm{L})^{3}$ & $9.98 \pm 0.23$ & $9.69 \pm 0.38$ & $9.87 \pm 0.15$ & $9.72 \pm 0.21$ & $9.95 \pm 0.08$ \\
\hline $\operatorname{ALP}(\mathrm{IU} / \mathrm{L})^{4}$ & $249.56 \pm 1.91^{\mathrm{ab}}$ & $252.88 \pm 2.77^{\mathrm{a}}$ & $240.24 \pm 4.54^{\mathrm{b}}$ & $238.36 \pm 5.22^{\mathrm{b}}$ & $249.41 \pm 2.74^{\mathrm{ab}}$ \\
\hline
\end{tabular}

${ }^{\mathrm{a}-\mathrm{b}}$ Mean \pm SE values $(n=10 /$ treatment) in a same row with different superscripts are significantly different $(P \leq 0.05)$

${ }^{1}$ Day-old broiler chicks were fed a corn-soybean meal based control diet. Control: without BMD, Non-AGP and PRO supplementation; BMD: control plus $400 \mathrm{mg} / \mathrm{kg}$ bacitracin methylene disalicylate; Non-AGP1: control plus $0.05 \%$ Non-AGP, Non-AGP2: control plus $0.1 \%$ Non-AGP; PRO: control plus $0.1 \%$ commercial probiotic for 42 days. At the middle and end of the experiment, blood samples were randomly obtained from 2 chickens per replicate ( 5 replicate per treatment) and analyzed for antibody titers.

${ }^{2}$ ALT: Alanine Aminotransferase.

${ }^{3}$ GGT: Gamma-glutamyl transferase.

${ }^{4}$ ALP: Alkaline phosphatase.

difference in all studied treatments. In the case of liver and kidney, significantly $(P \leq 0.05)$ higher values were noticed in Non-AGP1 and Non-AGP2 fed groups, compared with the control group, but for the pancreas weight, only the BMD and Non-AGP2 treatments were heavier than the control treatment. Bursa of Fabrecious relative weights were decreased significantly $(P \leq 0.05)$ in BMD and the Non-AGP treated groups, but the PRO treatment showed no significant change when compared with the control group.

\section{Discussion}

Data on performance are commonly used to assess the efficacy of feed additives in animal production systems (Manafi and Khosravinia, 2013). No changes were observed in the body weight of day-old chicks indicating that all chicks were in a similar range at the beginning, and continued till the d 28 of age. No difference among the treatments within the afore-mentioned periods demonstrates that feed additives should be consumed more in later periods to reflect their effects on performance of the chicks during these times. For the rest of the trial, higher body weights and better feed efficiency were found in BMD and most Non-AGP groups versus controls, which are similar to other reports on performance (La Vorgana et al., 2013). The lack of significant influence of the dietary treatments on performance during the first four weeks could be attributed to the composition of the basal diet and/or the environmental conditions. Our trial was performed under ideal conditions. Also, the diet fed in the different periods (Table 1) consisted of highly digestible ingredients so that bacterial growth in the intestine could be limited, and could affect the degree of growth promotion by treatments. Growth stimulating agents 
Table 4. Dietary effect of BMD, Non-AGP and PRO on Humoral immune response of chicks at 21 and 42 days ${ }^{1}$

\begin{tabular}{lccccc}
\hline \hline & & \multicolumn{5}{c}{ Treatments } \\
\hline Antibody titers (21 d) & Control & BMD & Non-AGP1 & Non-AGP2 & PRO \\
\hline ND $^{2}$ & $3.80 \pm 0.20$ & $3.80 \pm 0.35$ & $3.80 \pm 0.24$ & $3.80 \pm 0.38$ & $3.80 \pm 0.24$ \\
IBD $^{3}$ & $752.60 \pm 94.71$ & $749.00 \pm 45.20$ & $751.40 \pm 56.82$ & $753.60 \pm 44.26$ & $752.50 \pm 39.14$ \\
AI $^{4}$ & $3.70 \pm 0.15$ & $3.60 \pm 0.26$ & $3.60 \pm 0.26$ & $3.60 \pm 0.26$ & $3.70 \pm 0.30$ \\
Antibody titers (42 d) & & & & \\
ND & $3.80 \pm 0.32^{\mathrm{a}}$ & $4.90 \pm 0.31^{\mathrm{b}}$ & $4.10 \pm 0.34^{\mathrm{a}}$ & $4.80 \pm 0.46^{\mathrm{b}}$ & $3.90 \pm 0.37^{\mathrm{a}}$ \\
IBD & $242.10 \pm 40.79^{\mathrm{a}}$ & $358.70 \pm 58.18^{\mathrm{b}}$ & $339.00 \pm 35.32^{\mathrm{a}}$ & $356.00 \pm 27.56^{\mathrm{b}}$ & $240.50 \pm 4.44^{\mathrm{a}}$ \\
$\mathrm{AI}$ & $1.40 \pm 0.16^{\mathrm{a}}$ & $1.70 \pm 0.15^{\mathrm{b}}$ & $1.40 \pm 0.22^{\mathrm{a}}$ & $1.60 \pm 0.22^{\mathrm{b}}$ & $1.30 \pm 0.21^{\mathrm{a}}$ \\
\hline
\end{tabular}

${ }^{\mathrm{a}-\mathrm{b}}$ Mean \pm SE values $(n=10$ /treatment $)$ in a same row with different superscripts are significantly different $(P \leq 0.05)$

${ }^{1}$ Day-old broiler chicks were fed a corn-soybean meal based control diet. Control: without BMD, Non-AGP and PRO supplementation; BMD: control plus $400 \mathrm{mg} / \mathrm{kg}$ bacitracin methylene disalicylate; Non-AGP1: control plus $0.05 \%$ Non-AGP, Non-AGP2: control plus $0.1 \%$ Non-AGP; PRO: control plus $0.1 \%$ commercial probiotic for 42 days. At the middle and end of the experiment, blood samples were randomly obtained from 2 chickens per replicate ( 5 replicate per treatment) and analyzed for antibody titers.

${ }^{2}$ ND: Newcastle disease.

${ }^{3}$ IBD: Infectious Bursal Disease.

${ }^{4} \mathrm{AI}$ : Avian Influenza.

Table 5. Dietary effect of BMD, Non-AGP and PRO on Visceral organ weights of chicks ${ }^{1}$

\begin{tabular}{|c|c|c|c|c|c|}
\hline \multirow[b]{2}{*}{ Visceral organs $^{2}$} & \multicolumn{5}{|c|}{ Treatments } \\
\hline & Control & BMD & Non-AGP1 & Non-AGP2 & PRO \\
\hline Thymus & $4.20 \pm 0.13$ & $4.41 \pm 0.09$ & $4.20 \pm 0.16$ & $4.46 \pm 0.04$ & $4.24 \pm 0.03$ \\
\hline Spleen & $1.54 \pm 0.06$ & $1.48 \pm 0.03$ & $1.54 \pm 0.04$ & $1.50 \pm 0.06$ & $1.49 \pm 0.02$ \\
\hline bursa of Fabreciuos & $1.50 \pm 0.03^{\mathrm{a}}$ & $1.38 \pm 0.01^{\mathrm{b}}$ & $1.42 \pm 0.01^{\mathrm{b}}$ & $1.42 \pm 0.01^{\mathrm{b}}$ & $1.51 \pm 0.01^{\mathrm{a}}$ \\
\hline Liver & $25.98 \pm 0.21^{\mathrm{c}}$ & $30.10 \pm 0.68^{\mathrm{a}}$ & $27.60 \pm 0.31^{\mathrm{b}}$ & $29.80 \pm 0.29^{\mathrm{a}}$ & $26.74 \pm 0.23^{\mathrm{bc}}$ \\
\hline Kidney & $7.52 \pm 0.09^{\mathrm{c}}$ & $8.73 \pm 0.15^{\mathrm{a}}$ & $8.24 \pm 0.04^{\mathrm{b}}$ & $8.66 \pm 0.13^{\mathrm{a}}$ & $7.68 \pm 0.18^{\mathrm{c}}$ \\
\hline Pancreas & $4.33 \pm 0.06^{\mathrm{b}}$ & $4.69 \pm 0.08^{\mathrm{a}}$ & $4.34 \pm 0.01^{\mathrm{b}}$ & $4.68 \pm 0.18^{\mathrm{a}}$ & $4.36 \pm 0.02^{\mathrm{b}}$ \\
\hline Gizzard & $24.19 \pm 0.18$ & $25.01 \pm 0.32$ & $24.64 \pm 0.13$ & $24.95 \pm 0.16$ & $24.46 \pm 0.39$ \\
\hline
\end{tabular}

${ }^{\mathrm{a}^{-\mathrm{c}}}$ Mean \pm SE values $(n=10 /$ treatment $)$ in a same row with different superscripts are significantly different $(P \leq 0.05)$

${ }^{1}$ Day-old broiler chicks were fed a corn-soybean meal based control diet. Control: without BMD, Non-AGP and PRO supplementation; BMD: control plus $400 \mathrm{mg} / \mathrm{kg}$ bacitracin methylene disalicylate; Non-AGP1: control plus $0.05 \%$ NonAGP, Non-AGP2: control plus $0.1 \%$ Non-AGP; PRO: control plus $0.1 \%$ commercial probiotic for 42 days. At the end of the experiment, internal organs were randomly sampled from 2 chickens per replicate ( 5 replicate per treatment) weighed and used to calculate relative organ weights.

${ }^{2}$ Values are expressed as relative weight (g per kg live BW).

may have more impact on the performance when the diet used is less digestible. In addition, it was known that wellnourished, healthy chicks do not respond to antibiotic supplements provided that they are housed under clean and disinfected conditions ( $\mathrm{Li}$ et al., 2009). In the absence of BMD, Non-AGP at the higher level $(0.1 \%)$ could show a better performance than the control group, reaching to that of BMD at day 35. The beneficial effects of Non-AGP feed ingredients on broiler performance in this trial are in agreement with a large number of other research studies using natural promoting agents in broilers (Conner et al., 1993; Helander et al., 1998; Russo et al., 1998; Alçiçek et al., 2004; Horosova et al., 2006; Puvača et al., 2008; Puvača et al., 2013; Hedayati et al., 2014) compared to studies which do not reveal positive effects (Lee et al., 2003). The NonAGP product used in this study has phytomolecules (allicin, carvacrol, paprika, cinnamaldehyde, peppermint and thy- mol), Glucamannan oligosaccharides (derived from yeast cell wall), organic acids (propionic acid and fumaric acid) and Essential Oils (EOs) as its ingredients. An EO is a mixture of fragrant volatile compounds with various chemical compositions and concentrations (Lee et al., 2003). The reason for the performance improvement in Non-AGP groups in the current study might be due to the fact that herbs from which EOs are derived will positively affect food digestion (Burt et al., 2004; Kohlert et al., 2000), stimulating the bile salt secretion and digestive enzyme activities of the intestinal mucosa of the pancreas (Helander et al., 1998; Burt et al., 2004) through antibacterial, antifungal, antiviral, and antiprotozoal properties of phytomolecules, leading to 'ideal flora' that would allow optimum growth performance (Bampidis et al., 2005; Cross et al., 2007). Glucamannan oligosaccharides prevents proliferation of gut pathogens and captures the hostile gut wall attacking bacteria like E.coli by 
locking into the bacterial molecular structure and facilitating their carry them outside. On the other hand, organic acids and their salts will positively affect the performance due to the presence of naturally occurring substances many of which play important roles in metabolism (Izat et al., 1990). In addition to the sanitary role of such acids in animal feed, they could modify the $\mathrm{pH}$ of both the feed and the digestive tract of poultry (Hedayati et al., 2014). Organic acids in their un-dissociated form are able to pass through the bacterial cell membrane inside the cell and as a result, the pathogenic microorganisms are unable to replicate efficiently and the microflora of the digestive tract is modified (Izat $e t$ al., 1990).

In this trial, the activities of albumin, globulin, total protein, ALT and GGT were found to be non-altered in all groups. Only ALP was influenced significantly $(P \leq 0.05)$ in both levels of Non-AGP treatments when compared with BMD. Our results are in partial agreement with reported findings of many scientists who stated that feed additives did not affect levels of total protein, albumin, globulin, AST, ALT, triglycerides, cholesterol, HDL, LDL and VLDL in blood plasma on broilers (Piva et al., 1994; Attia et al., 2001; Attia et al., 2003; Attia et al., 2006; Ashaverizadeh et al., 2009). One reason is that a phytogenic compound reduces enteric diseases and eliminates subsequent contamination of poultry products (Giannenas et al., 2002; Bampidis et al., 2005). Another positive role of phytomolecules is supposed to be their anti-microbial activities. The lipophilic property and chemical structure of EO present in this product could play a role in manipulation of the enzyme activities inside the body of broilers (Cross et al., 2007; Hedayati et al., 2014). Presence of organic acids in poultry feed also is reported to decrease the intraluminal concentration of coliform bacteria and other acid-intolerant organisms such as Campylobacter and Salmonella known to be involved in digestive disorders (Izat et al., 1990; Hedayati et al., 2014).

The humoral immune response of chicks fed different treatment groups at d 21 remained non-significant compared with the control on ND, IBD and AI titer values. This indicates that this feed additive may not have an influence on the juvenile stage of chicks. At d 42, the situation changed thoroughly and all levels of antibody titers in BMD and the $0.1 \%$ Non-AGP were significantly different from the control group. This suggests that Non-AGP at the higher level may also influence immunity of birds, clearly indicating that the feed additives used in this study have a direct influence on the antibody titers of chicks at this age (Talebi et al., 2008). Feeding various natural feed additives stimulate different aspects of the gut-associated immunity along with decreasing the pathogenic bacteria in chickens (Koenen et al., 2004). In addition, it has been reported that natural-based feed additives enhances immune function and promotes the synthesis of endogenous antimicrobial peptides in the gut (Paturi et al., 2007; Li et al., 2009). It is believed that active ingredients present in phytomolecules can penetrate the membrane of the bacteria and reach the inner part of the cell because of their lipophilic properties which could lead to the enhancement of overall immunity (Najafi and Torki, 2010; Foroughi et al., 2011). Glucamannan oligosaccharide derived from yeast cell wall stimulates immunity. The immune stimulation effect is primarily due to stimulation of the Reticulo Endothelial System, which in turn produces an increased amount of the macrophages that play a key role in the body's natural immune system. It also has therapeutic value in combating a variety of diseases caused by bacteria, fungi and viruses. Another reason for enhancement of immunity in Non-AGP fed birds goes back to reducing colonization of pathogenic microorganisms due to the presence of organic acids (Izat et al., 1990). Therefore, the ability of Phytogenic Feed Additives (PFA) to increase the immune system is a viable reason for supporting their use as an alternative to antibiotics for improving poultry health and production.

In this trial, except for Non-AGP1 did not significantly alter the pancreas weight, the weight of the liver, kidney and pancreas were increased and the Bursa of Fabrecious was decreased by BMD and Non-AGP treatments. In a study of Najafi and Torki (2010), no significant changes were observed in liver, pancreas, bursa, spleen, gizzard, thymus and heart of the broilers fed diets supplemented with essential oils of thyme, cinnamon and clove. In another study, Chinajariyawong and Muangkeow (2011) reported no effect on carcass yield and relative weight of visceral organs of chicks fed EO of palm kernel meal. The lack of any significant effect of probiotic on carcass characteristics, organs and most meat quality was reported earlier (Attia et al., 2003; Selle et al., 2006; Attia et al., 2011). In a study by Ashom et al., (2014) statistical changes were observed only for the pancreas, whereas the liver, heart, proventriculus and spleen of broilers remained unchanged when fed Roselle seed meal diets.

In this trial, the PRO fed chicks showed no significant changes when compared with control group, in all studied parameters. Ferreira and Kussakawa (1999) reported that probiotics do not always have positive outcomes in poultry. This is due to several factors like flock health, duration of poultry house downtime and environmental contamination levels. In addition, the appropriate concentrations / levels of probiotic administration is the key factor to be considered. Therefore, the beneficial effects of a particular probiotic are strictly dependent on characteristics and quantity of microorganism strains used in the probiotic preparation (Tournut, 1998). The result of the current study is in accordance with findings of other reports (Takahashi et al., 2005; Nunes et al., 2012).

The phytomolecules and organic acids present in this product may show their effects through an anti-microbial mode of action, biological effects, flavor effects, effect on the digestion process through microflora and fat digestibility, impact on lipid metabolism and/or effects on growth performance in chickens.

\section{Conclusions}

1. Chicks fed BMD had a significant $(P \leq 0.05)$ increase in 
the body weight, feed efficiency, ND, IBD and AI titers and liver, kidney and pancreas weights.

2. Chicks fed two levels of Non-AGP in their diet have shown a significant increase $(P \leq 0.05)$ at $0.1 \%$ of NonAGP administration in many of the studied parameters and reached BMD values. At both Non-AGP administration levels, the values for ALP were reduced versus BMD, but not the control treatment.

3. It seems that both levels of provided Non-AGP could enhance the studied parameters to some extent; nevertheless, values in the Non-AGP $0.1 \%$ group were generally found to be very close to the values of BMD group.

4. Addition of a commercial probiotic generally did not show a positive response when compared with the data of BMD and $0.1 \%$ Non-AGP values.

5. The potential use of Non-AGP at the level of $0.1 \%$, as an alternative to BMD in commercial chicken production is recommended.

\section{References}

Alçiçek A, Bozkurt M and Çabuk M. The effect of a mixture of herbal essential oils, an organic acid or a probiotic on broiler performance. South African Journal of Animal Science, 34: 217-222. 2004.

Ashaverizadeh A, Dabiri N, Ashaverizadeh O, Mirzadeh KH, Roshanfekr $\mathrm{H}$ and Mamooee M. Effect of dietary antibiotic, probiotic and prebiotic as growth promoters on growth performance, carcass characteristics and hematological indices of broiler chickens. Pakistan Journal of Biological Science, 12: 52-59. 2009.

Ashom SA, Tuleun CD and Carew SN. Growth, carcass and internal organ characteristics of finisher broiler chickens fed processed Roselle (Hibiscus sabdariffa L.) seed meal diets. Journal of Biological and Agricultural Healthcare, 4: 141-146. 2014.

Attia YA, Abdel-Rahman SA and Qota EMA. Effects of microbial phytase with or without cell-wall splitting enzymes on the performance of broilers fed suboptimum levels of dietary protein and metabolisable energy. Egyptian Poultry Science, 21: 521-547. 2001.

Attia YA. Performance, carcass characteristics, meat quality and plasma constituents of meat type drakes fed diets containing different levels of lysine with or without a microbial phytase. Achieve of Animal Nutrition, 57: 39-48. 2003.

Attia YA, Böhmer B and Roth-Maier DA. Responses of broiler chicks raised under constant relatively high ambient temperature to enzymes, amino acid supplementations, or diet density. Archiv für Geflügelk. 70: 80-91. 2006.

Attia YA, Zeweil HS, Alsaffar AA and El-Shafy AS. Effect of nonantibiotic feed additives as an alternative to flavomycin on productivity, meat quality and blood parameters in broilers. Arch. Geflügelk, 75: 40-48. 2011.

Aviagen. Ross 308: Broiler Nutrition Specification. Aviagen Inc., Huntsville, AL. 2007.

Boehringer Mannhein Hitachi 704 automatic analyzer, Japan.

Bampidis VA, Christodoulou V, Florou Paneri P, Christaki E, Vhatzopoulou PS, Tsiligianni T and Spais AB. Effect of dietary dried oregano leaves on growth performance, carcase characteristics and serum cholesterol of female early maturing turkeys. British Poultry Science, 5: 595-601. 2005.

Burt S. Essential oils: their antibacterial properties and potential applications in foods-a review. International Journal of Food Microbiology, 94: 223-253. 2004.

CEVA SANTE ANIMALE, Libourne, France.

Conner DE. Naturally occurring compounds. In Antimicrobials in Foods, Davidson, P. M., and A. L. Branen, eds. Dekker, New York. pp: 441-468. 1993.

Chinajariyawong $\mathrm{C}$ and Muangkeow N. Carcass yield and visceral organs of broiler chickens fed palm kernel meal or Aspergillus wentii TISTR 3075 fermented palm kernel meal. Walailak Journal of Science and Technology, 8: 175-185. 2011.

Cross DE, Mcdevith RM, Hillman K and Agamovic T. The effect of herbs and their associated essential oils on performance, digestibilities and gut microflora in chickens 7 to $28 \mathrm{~d}$ of age. British Poultry Science, 4: 496-506. 2007.

Duncan DB. Multiple range and multiple F tests. Biometrics, 11: 1-42. 1955.

Ferreira FAB and Kussakawa KCK. Probióticos. Biotecnologia., Ciência and Desenvolvimento, 8: 40-43. 1999.

Foroughi AR, Mousavinejad HT and Saleh H. The effect of essential oils of Thyme (thymus vulgaris) into performance and humarl immune response of broiler chicks. Agricultural Journal, 6: 299-302. 2011.

Giannenas I, Florou-Paneri P, Papazahariadou M, Christaki E, Botsoglou NA and Spais AB. Effect of dietary supplementation with oregano essential oil on performance of broilers after experimental infection with Eimeriatenella. Archive of Animal Nutrition, 57: 99-106. 2003.

Hammer KA, Carson CF and Riley TV. Antimicrobial activity of essential oils and other plants extracts. Journal of Applied Microbiology, 86: 985-990. 1999.

Hedayati M, Manafi M, Yari M and Avara A. The influence of an acidifier feed additive on biochemical parameters and immune response of broilers. Annual Research and Review in Biology, 4: 1637-1645. 2014.

Helander IM, Alakomi HL, Latva-Kala K, Mattila-Sandholm T, Pol I, Smid EJ, Gorris LGM and Von Wright A. Characterization of the action of selected essential oil components on gramnegative bacteria. Journal of Agricultural and Food Chemistry, 46: 3590-3595. 1998.

Horosova K, Bujnakova B and Kmet V. Effect of oregano essential oil on chicken lactobacilli and E. coli. Folia Microbiology, 51: 278-280. 2006.

HIPRAVIAR ${ }^{\circledR}$ CLON, Amer, Spain.

Izat AL, Tidwell NM, Thomas RA, Reiber MA, Adams MH, Colberg $\mathrm{M}$ and Waldroup PW. Effects of a buffered propionic acid in diets on the performance of broiler chickens and on the microflora of the intestine and carcass. Poultry Science, 69: 818-826. 1990.

Kamel C. Tracing modes of action and the roles of plant extracts in non-ruminants. Pages 135-150 in Recent advances in animal nutrition. Garnsworthy P C and J Wiseman eds. Nottingham University Press, Nottingham. 2001.

Koenen ME, Van Der Hulst R, Leering M, Jeurissen SH and Boersma WJ. Development and validation of a new in vitro assay for selection of probiotic bacteria that express immune stimulating properties in chickens in vivo. FEMS Immunology \& Medical Microbiology. 40: 119-127. 2004.

Kohlert C, Van Rensen I, März R, Schindler G, Graefe EU and Veit M. Bioavailability and pharmacokinetics of natural volatile terpenes inanimals and humans. Planta Med. 66: 495-505. 2000.

La Vorgana M, Schaeffer LJ, Bade D, Dickson J, Cookson K and 
Davis SW. Performance of broilers fed a broader spectrum antibiotic (virginiamycin) or a narrower spectrum antibiotic (bacitracin methylene disalicylate) over 3 consecutive growout cycles. Journal of Applied Poultry Research, 22: 574-582. 2013.

Lee KW, Everts H, Kappert HJ, Frehner M, Losa R and Beynen AC. Effects of dietary essential oil components on growth performance, digestive enzymes and lipid metabolism in female broiler chickens. British Poultry Science, 44: 450-457. 2003.

Li SP, Zhao XJ and Wang JY. Synergy of Astralagus polysaccharides and probiotics (Lactobacillus and Bacilluscereus) on immunity and intestinal microbiota in chicks. Poultry Science, 88: 519-525. 2009.

Manafi $M$ and Khosravinia $H$. Effects of aflatoxin on the performance of broiler breeders and its alleviation by herbal mycotoxin binder. Journal of Agricultural Sciences and Technology, 15: 55-63. 2013.

Najafi P and Torki M. Performance, blood metabolites and immunocompetaence of broiler chicks fed diets included essential oils of medicinal herbs. Journal of Animal and Veterinary Advances, 9: 1164-1168. 2010.

Nunes RV, Scherer C, Pozza PC, Eyng C, Bruno LDG and Vieites FM. Use of probiotics to replace antibiotics for broilers. Research Bras Zootechnology, 41: 2219-2224. 2012.

Patterson JA and Burkholder KM. Application of prebiotics and probiotics in poultry production. Poultry Science, 82: 627631. 2003.

Paturi G, Phillips M, Jones M and Kailasapathy K. Immune enhancing effects of Lactobacillus acidophilus LAFTIL10 and Lactobacillus paracasei LAFTIL26 in mice. International Journal of Food Microbiology, 115: 115-118. 2007.

Piva G, Morlacchini MG, Beretta CC and Prandini A. Microbial phytase from Aspergillus niger in the feeding of broiler chickens. Rivista. di. Avicoltura, 63: 33-38. 1994.

Puvača N. Effect of phytoadditive (Allium sativum L.) in fattening chicks nutrition. Pages $116^{-121}$ in Proc. 32nd Int. Con. Agr., Novi Sad. 2008.

Puvača N, Stanaćev V, Glamočić D, Lević J, Perić L, Stanaćev V and Milić D. Beneficial effects of phytoadditives in broiler nutrition. World's Poultry Science Journal, 69: 27-34. 2013.

Reisinger N, Steiner T, Nitsch S, Schatzmayr G and Applegate TJ.
Effects of a blend of essential oils on broiler performance and intestinal morphology during coccidial vaccine exposure. Journal of Applied Poultry Research, 20: 272-283. 2011.

Russo M, Galletti G, Bocchini P and Carnacini A. Essential oil chemical composition of wild populations of Italian oregano spice. Journal of Agricultural and Food Chemistry, 46: 37413746. 1998.

SAS User's Guide. Version 8 ed. SAS Inst. Inc., Cary, NC. 2001.

Selle PH, Creswell D, Cadogan C, David J, Partridge GG and Scott T. Phytase supplementation of wheat based broiler diets reduces dependence on meat and bone meal. Poultry Science, 43: 330-338. 2006.

Stanaćev V, Kovčin S, Arapović Ž, Milošević N, Filipović S, Božić $A$ and Stanaćev V. Influence of garlic involved in feed for fattening chicks on production parameters. Contemporary Agriculture, 57: 201-207. 2008.

Takahashi SE, Mendes AA, Saldanha ESPB, Pizzolante CC, Pelícia K, Quinteiro RR, Komiyama CM, Garcia RG and Almeida PICL. Efficiency of prebiotics and probiotics on the performance, yield, meat quality and presence of Salmonella spp in carcasses of free-range broiler chickens. Brazilian Journal of Poultry Science, 7: 151-157. 2005.

Talebi A, Amirzadeh B, Mokhtari B and Gahri H. Effects of a multistrain probiotic (PrimaLac) on performance and antibody response to Newcastle disease virus and infectious bursal disease vaccination in broiler chickens. Avian Pathology, 37: 509-512. 2008.

Tournut JR. Probiotcs. In: REUnião Da SociedadeBrasileira De Zootecnia, 35, 1998, Botucatu. Anais... Botucatu: SBZ. 179199. 1998.

Windisch W, Schedle K, Plitzner C and Kroismayr A. Use of phytogenic products as feed additives for swine and poultry. Journal of Animal Science, 86: 140-148. 2008.

Yeo $\mathrm{J}$ and Kim K. Effect of feeding diets containing an antibiotic, a probiotic, or yucca extract on growth and intestinal urease activity in broiler chicks. Poultry Science, 76: 381-385. 1997.

Young J, Stagsted J, Jensen J, Karlsson A and Heckel P. Ascorbic acid atocopherol and oregano supplements reduce stress induced deterioration of chicken meat quality. Poultry Science, 82: 1343-1351. 2003. 